CLINICAL STUDY

\title{
Circulating ghrelin levels in girls with central precocious puberty are reduced during treatment with LHRH analog
}

\author{
Claudio Maffeis ${ }^{1}$, Roberto Franceschi ${ }^{1}$, Paolo Moghetti ${ }^{2}$, Marta Camilot $^{1}$, Silvana Lauriola ${ }^{1}$ and Luciano Tatò ${ }^{1}$ \\ ${ }^{1}$ Department of Mother and Child, Biology-Genetics, Section of Pediatrics and ${ }^{2}$ Department of Biomedical and Surgical Sciences, Endocrinology Unit, \\ University of Verona, P.le L.A. Scuro, 10, 37134 Verona, Italy
}

(Correspondence should be addressed to C Maffeis; Email: claudio.maffeis@univrit)

\begin{abstract}
Decreased levels of ghrelin have been measured in growing children during puberty. No data are available for girls with central precocious puberty (CPP).

Aims: To explore ghrelin changes before, during, and after GnRH analog treatment in girls with CPP. Subjects and methods: A sample of 20 Caucasian girls ( $8.08 \pm 0.65$ years of age) with CPP was recruited. Height and weight, bone age, LH, FSH, $17 \beta$ estradiol $\left(\mathrm{E}_{2}\right)$, and ghrelin were measured before starting treatment with GnRH analog, 18 months after therapy began and again 6 months after therapy discontinuation.

Results: LH and $\mathrm{E}_{2}$ serum levels decreased significantly during treatment $(2.45 \pm 2.03$ vs $0.67 \pm$ $0.49 \mathrm{UI} / \mathrm{l}, P<0.01$ and $28.17 \pm 9.7 \mathrm{vs} 15 \mathrm{pmol} / \mathrm{l}, P<0.01$ respectively), returning to baseline levels after the discontinuation of therapy $(4.75 \pm 1.66 \mathrm{UI} / \mathrm{l}$ and $29.23 \pm 6.99 \mathrm{pmol} / \mathrm{l}$ respectively). $\mathrm{LH}$ peaked following LHRH stimulation significantly $(P<0.01)$ decreased during treatment $(24.45 \pm$ 14.17 vs $1.3 \pm 0.18 \mathrm{UI} / \mathrm{l})$ and then increased after therapy discontinuation $(12.58 \pm 6.09, P<0.01)$. Ghrelin decreased significantly $(P<0.05)$ during treatment $(1849 \pm 322$ vs $1207 \pm 637 \mathrm{pg} / \mathrm{ml})$, and increased, though not significantly $(P=0.09)$ after therapy withdrawal $(1567 \pm 629 \mathrm{pg} / \mathrm{ml})$.

Conclusions: Contrary to what is expected in physiologic puberty, where ghrelin is progressively reduced, the prepubertal hormone milieau induced by GnRHa treatment in patients suffering from central precocious puberty (CPP) did not promote an increase in ghrelin circulating levels. Therefore, in CPP, ghrelin secretion seems to be independent from pubertal development per se. Concomitant estrogen suppression during treatment may play a potential role in the regulation of ghrelin secretion in these girls.
\end{abstract}

European Journal of Endocrinology 156 99-103

\section{Introduction}

CPP is characterized by early activation of the pituitarygonadal axis, which leads to the increased growth velocity and the development of secondary sexual characteristics. The growth spurt in CPP, like that in normal puberty, is determined by the gonadal hormones that stimulate spontaneous growth hormone $(\mathrm{GH})$ secretion, which in turn, activates the insulin-like growth factor-I (IGF-I) axis $(1,2)$. Treatment of CPP with gonadotropin-releasing hormone analogs (GnRHa) stops pubertal development and slows growth velocity. In some studies, GH secretion was found to decrease with the decline of gonadal steroids $(1,3-5)$. Recently, the reduction of the IGF-I ternary complex formation was attributed to a reduction of ALS (acid-labile subunit of human ternary insulin like the growth factor-binding protein complex), whereas there was no change in IGF-I and IGF-binding protein (IGFBP)-3 levels (4). However, several other hormones, for instance, somatostatin and GHRH, affect GH secretion (6). Ghrelin, a gut-derived peptide which is also involved in appetite stimulation and reduction of fat utilization, is one of these hormones (7-13). During puberty, a progressive reduction in ghrelin levels has been reported (14-16). The reason why ghrelin secretion decreases at puberty is not yet known (17). To the best of our knowledge, no data are available on ghrelin levels in young girls with precocious puberty treated with GnRHa. In particular, it is not known whether treatment leading to a prepubertal hormone milieau is able to modify post-absorptive ghrelin levels, resetting its secretion to prepubertal conditions. We hypothesized that the normal decline in ghrelin reported in physiological puberty may be reversed by treatment. Therefore, the aim of this study was to investigate how ghrelin changes in girls with CPP before, during, and after GnRHa treatment.

\section{Subjects and methods}

\section{Subject population}

Ours was a longitudinal study on 20 Caucasian girls with CPP, defined as the onset of breast development 
before the age of 8 years associated with a pulsatile pattern of pituitary gonadotropin secretion and a pubertal response to exogenous $\mathrm{GnRH}$ in the absence of any identifiable adrenal or gonadal pathology (18). The average time between the onset of breast development and the start of treatment was $9 \pm 3$ months (range 4-14 months). At the beginning of therapy, the girls had a chronological age of $8.08 \pm 0.65$ years, accelerated bone age by 2 years $(10.13 \pm 0.77$ years $)$, a longitudinal uterus diameter measured by pelvic ultrasound $>3.5 \mathrm{~cm}$; an luteinizing hormone $(\mathrm{LH})$ peak $>7$ IU/l after luteinizing hormone-releasing hormone (LHRH) load, and an follicle-stimulating hormone $(\mathrm{FSH}) / \mathrm{LH}$ ratio $<1$. Before starting treatment, the patients underwent neuroradiological tests. Progressive organic diseases of the central nervous system and gonadic, adrenal or thyroidal diseases were excluded. The patients had not been treated previously with steroid inhibitors. Each subject received injections of the GnRH analog, decapeptyl depot (D-Trp6-GnRH, IPSEN-Biotech, Milan, Italy) at a dose of $3.75 \mathrm{mg}$ every 28 days for an average period of $2.5 \pm 1.5$ years.

\section{Experimental design}

The study protocol was in accordance with the 1975 Declaration of Helsinki, as revised in 1983, and informed consent was obtained from the parents before each subject was enrolled in the study. The subjects were recruited at the Pediatric Endocrinology Unit of the University Hospital of Verona. A clinical examination and biochemical tests were performed before, at 3-6month-interval during, and 6 months after $\mathrm{GnRH}$ withdrawal.

Standing height was measured in the morning at least $30 \mathrm{~min}$ after the subject's rising using a wallmounted stadiometer (Harpendorf Holtain Ltd, Crymmith, UK), and the average of three replicates is reported. Weight was measured on a standard physician's beam scale, with the subject dressed only in light underwear and no shoes. The body mass index (BMI) was calculated as weight (kilograms) divided by height squared (meters squared). The BMI percentiles reported by regional BMI tables were used as reference (19). We used BMI as an index of overweight as there is general consensus that it is a reliable and clinically valid index of body fatness, correlating with other measures of adiposity, in particular dual energy X-ray absorptiometry (OXA) (20-22). Puberty development was clinically assessed on the basis of Tanner Stages (23).

Single serum samples were obtained from girls in the morning in fasting condition to measure total ghrelin, before treatment, 18 months after GnRHa initiation, and 6 months after therapy withdrawal. After venous blood centrifugation, serum samples were immediately frozen. Hormone concentration in all serum samples was assayed on the same day in duplicates, using a pool of several kits of the same lot number.
Basal and GnRH-stimulated levels of gonadotropins and $17 \beta$ estradiol $\left(E_{2}\right)$ were evaluated after an i.v. injection of exogenous GnRH, before 18 months after GnRHa initiation and 6 months after discontinuation of treatment. Pelvic US was performed every 6 months.

Bone age at recruitment, at 12-month-interval during therapy and at discontinuation of treatment was assessed by the same investigator using an X-ray of the left hand according to the Greulich and Pyle method (24).

Neuroradiological examinations consisted of magnetic resonance imagings of the hypothalamo-pituitary region.

Serum LH, FSH, and $\mathrm{E}_{2}$ were measured by enzyme immunoassay (LH and FSH, Bioserv Diagnostics, Rostock, Germany; E $E_{2}$, Research Diagnostics Inc., Flanders, NJ, USA). Seric ghrelin was dosed by a commercial RIA kit (Linco Research Inc., St Charles, MO, USA) according to the manufacturer's instructions. The assay detects octanoylated human ghrelin with a sensitivity of $100 \mathrm{pg} / \mathrm{ml}$. The inter- and intra-assay coefficients of variation were $2.6-4.7$ and 3.5-5.5\% respectively.

The sensitivities of the enzyme immunoassays were $0.3 \mathrm{IU} / \mathrm{l}$ for $\mathrm{LH}$ and $\mathrm{FSH}$ and $15 \mathrm{pmol} / \mathrm{l}$ for $\mathrm{E}_{2}$ respectively. The values of $0.2 \mathrm{IU} / \mathrm{l}$ (for $\mathrm{LH}$ and FSH) and $15 \mathrm{pmol} / \mathrm{l}$ (for $\mathrm{E}_{2}$ ) were assigned to samples below the detection limit.

\section{Statistical analysis}

Data are shown as mean (s.D.). The Wilcoxon-signed ranks test was used to compare physical characteristics as well as circulating hormones before, during, and after treatment. Correlation among variables was calculated using the Spearman correlation analysis. A level of significance of $P<0.05$ was used for all data analyses. Statistical analyses were done using SPSS 13.0 software for Windows.

\section{Results}

Growth parameters for the girls are shown in Table 1. Girls with CPP were initially heavier and taller than the reference average for age: their BMI z-scores were initially rather high for both chronological age (CA; BMI $z$-score: $0.71 \pm 0.82$ ) and bone age (BA; BMI $z$-score: $0.27 \pm 0.79)$. After GnRHa-induced suppression of gonadal sex steroids, the rates of linear growth (growth velocity; GV) and skeletal maturation (BA:CA ratio) slowed $(P=0.09$ and $P<0.01$ respectively). During GnRHa treatment, body weight increased significantly $(P<0.001)$, whereas BMI $z$-scores for CA showed a slight, but not significant increase. The treatment was accompanied by a reduction in the interval between CA and BA, whereas the BMI z-scores for BA increased, though not significantly. BMI $z$-scores for both CA and BA did not change significantly in the 6-10 months after therapy withdrawal. 
Table 1 Chronological age (CA), bone age (BA), BA:CA ratio, height $(\mathrm{H})$, growth velocity (GV), weight (W), body mass index (BMI), before, during, and after treatment in 20 girls with central precocious puberty.

\begin{tabular}{lccc}
\hline & Before treatment & During treatment (18 months) & After treatment (6 months) \\
\hline BA (years) & $10.13 \pm 0.77$ & $10.85 \pm 0.61^{\ddagger}$ & $12.41 \pm 0.09^{\Phi}$ \\
BA:CA ratio & $1.26 \pm 0.10$ & $1.13 \pm 0.07^{\dagger}$ & $1.06 \pm 0.09^{\| \prime}$ \\
H (cm) & $134.4 \pm 0.06$ & $143.3 \pm 0.06^{\ddagger}$ & $153 \pm 0.06^{\varpi}$ \\
H z-score for CA & $4.30 \pm 1.88$ & $4.20 \pm 1.01$ & $4.76 \pm 1.37$ \\
H Z-score for BA & $2.59 \pm 1.21$ & $3.42 \pm 1.10^{\dagger}$ & $4.36 \pm 1.32^{\S}$ \\
GV (cm/year) & $9.51 \pm 2.66$ & $8.71 \pm 4.55$ & $5.98 \pm 5.52$ \\
W (kg) & $33.10 \pm 4.34$ & $41.96 \pm 5.07^{\ddagger}$ & $48.1 \pm 8.0^{\pi}$ \\
BMl & $18.44 \pm 2.24$ & $20.38 \pm 2.53$ & $19.3 \pm 5.86$ \\
BMl z-score for CA & $0.71 \pm 0.82$ & $0.97 \pm 0.87$ & $0.69 \pm 0.77$ \\
BMl z-score for BA & $0.27 \pm 0.79$ & $0.72 \pm 0.92$ & $0.49 \pm 0.94$
\end{tabular}

Before versus during treatment: ${ }^{\dagger} P<0.01 ;{ }^{\ddagger} P<0.001$. During versus after withdrawal: ${ }^{\S} P<0.05 ;{ }^{\|} P<0.01 ;{ }^{\mathbb{T}} P<0.001$. Data are shown as means (s.D.).

During treatment, LH serum levels decreased significantly compared with baseline values $(2.45 \pm 2.03$ vs $0.67 \pm 0.49 \mathrm{UI} / \mathrm{l}, P<0.001)$, but they increased after therapy withdrawal $(4.75 \pm 1.66 \mathrm{UI} / \mathrm{l}, P<0.001)$. LH peak following LHRH stimulation significantly $(P<$ $0.01)$ decreased during treatment $(24.45 \pm 14.17$ vs $1.3 \pm 0.18 \mathrm{UI} / \mathrm{l})$ and it increased after therapy discontinuation (12.58 $\pm 6.09 \mathrm{UI} / \mathrm{l}, P<0.01$; Fig. 1$)$.

Similarly, treatment caused a significant $(P<0.001)$ reduction of $E_{2}$, which returned to baseline levels after therapy withdrawal (Fig. 2).

During GnRHa treatment, ghrelin concentrations decreased significantly $(P<0.01)$. Six months after treatment withdrawal, ghrelin increased slightly but did not reach the pre-treatment levels (Fig. 2). These changes paralleled those of serum $\mathrm{E}_{2}$ and $\mathrm{LH}$.

Individual changes of ghrelin and $\mathrm{E}_{2}$ did not correlate (before versus during treatment: $r=0.07, P=0.78$; during versus after treatment: $r=-0.16, P=0.49$ ).

\section{Discussion}

The main finding of our study was that ghrelin circulating levels decreased significantly during treatment with GnRHa, paralleling changes of LH and estradiol, and did not significantly increase after therapy discontinuation, failing to return to pretreatment levels. Therefore, ghrelin variation between the pre-treatment period and during the inhibition of puberty takes an opposite direction than that reported in physiological puberty, where ghrelin is progressively reduced during the puberty process (14-16). Although GnRHa treatment leads to a prepubertal hormone milieau, that is not enough to return ghrelin levels to prepubertal conditions, i.e., to a higher level.

A close relationship between ghrelin and BMI has been previously demonstrated (25). In the sample of girls participating in this study, BMI $z$-scores changed and the direction of variation in BMI appeared to be inversely related to the changes in ghrelin. However, it is unlikely that small changes in BMI $z$-scores, which are not statistically significant, could explain ghrelin changes during GnRH analog treatment.

Ghrelin has been shown to exert potent GH-releasing activity (8). Moreover, estrogen, among other hormones, has been shown to increase GH secretion by means of still undefined mechanisms $(1,2)$. Increase in estrogens at puberty stimulate spontaneous $\mathrm{GH}$ secretion, which, in turn activates the IGF-I axis $(1,2)$. In CPP, an early activation of the pituitarygonadal axis leads to increased growth velocity and the development of secondary sexual characteristics. It has been suggested that ghrelin may mediate the effects of

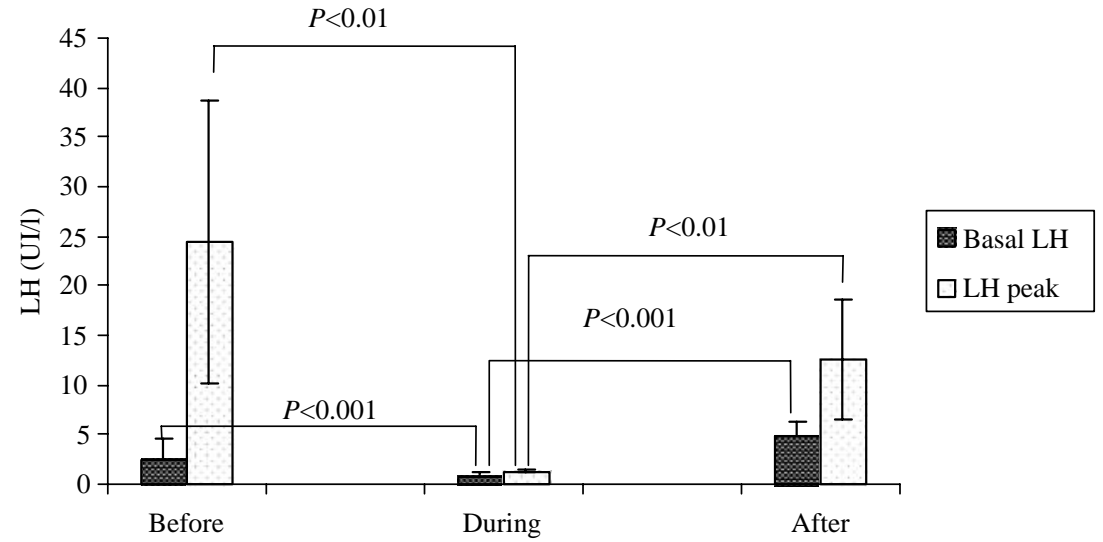

Figure 1 Basal luteinizing hormones (LH) levels and LH peak concentrations following luteinizing hormone-releasing hormone (LHRH) stimulation, in girls with central precocious puberty at initiation $(2.45 \pm 2.03$ and $24.45 \pm 14.17 \mathrm{UI} / \mathrm{I}$ respectively), during gonadotropin-releasing hormone treatment $(0.67 \pm 0.49$ and $1.3 \pm 0.18 \mathrm{UI} / /$ respectively) and after discontinuation $(4.75 \pm 1.66$ and $12.58 \pm$ $6.09 \mathrm{UI} / \mathrm{I}$ respectively). 

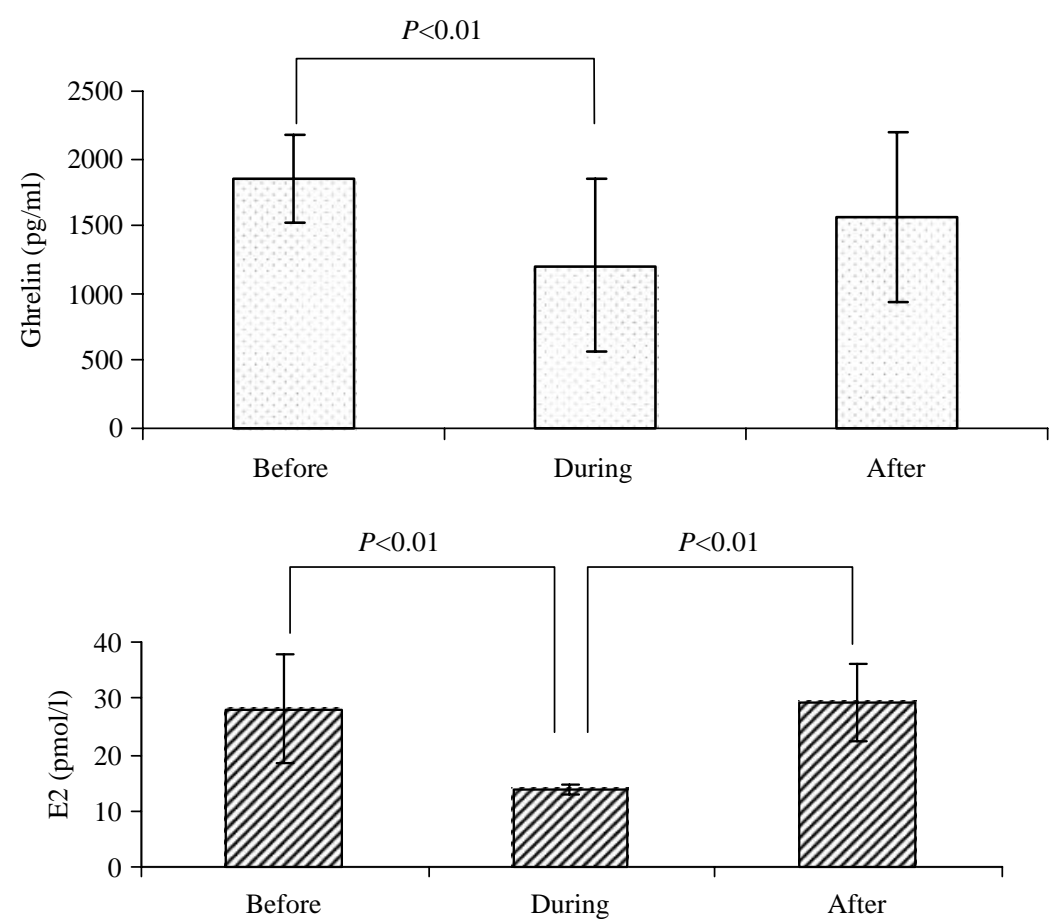

Figure 2 (top) Ghrelin circulating levels in girls with CPP at initiation $(1.849 \pm 322 \mathrm{pg} / \mathrm{ml})$, during $\mathrm{GnRH}$ treatment $(1.207 \pm 637 \mathrm{pg} / \mathrm{ml})$ and after discontinuation $(1.567 \pm 629 \mathrm{pg} / \mathrm{ml})$. (bottom) $17 \beta$ estradiol $\left(E_{2}\right)$ circulating levels in girls with CPP at initiation $(28.17 \pm 9.75 \mathrm{pmol} / \mathrm{l})$, during $(15 \pm 0.00 \mathrm{pmol} / \mathrm{l}) \mathrm{GnRH}$ treatment and after discontinuation $(29.23 \pm 6.99 \mathrm{pmol} / \mathrm{l})$. estrogen on the GH-axis (26). However, at puberty, gonadotropins, estradiol, and $\mathrm{GH}$ concentrations increase, whereas ghrelin levels decrease (14-16). These changes of ghrelin are affected by gender: boys have a greater decrease than girls (15). The reasons why ghrelin changes at puberty are not known (17).

In our study, treatment with GnRHa was associated with a reduction in circulating estrogen levels to prepubertal concentrations and in ghrelin as well. This behavior is different than that reported for physiological puberty, where estrogen increases and ghrelin decreases. Moreover, after therapy withdrawal, both estrogen and ghrelin increase. The relationship between estrogen and ghrelin was investigated in several studies done on both animals and humans. Animal studies have shown that estrogen is involved in the regulation of ghrelin secretion and directly induced ghrelin gene expression (27). Ovariectomy induced a reduction in the number of ghrelin-producing cells, ghrelin mRNA levels in gastric cells, and plasma ghrelin levels in rats. Administration of $17 \beta$ estradiol was able to reverse these changes (27). Similar findings were reported in humans. Estrogen replacement therapy in 64 hysterectomized post-menopausal women receiving peroral estrogen or transdermal estrogen therapy for 6 months increased active plasma ghrelin, and the relative changes in the levels of this hormone were positively associated with the relative changes in serum estradiol concentrations (28).

However, in other clinical conditions, the relationship between estrogen and ghrelin are not consistent with the above reported facts. In particular, a study conducted on a group of rather short peri-pubertal children (17) did not show changes in ghrelin concentration after a supraphysiological increase in estradiol levels was induced in girls via oral estrogens. The reasons that justify these results are not known. However, the experimental design was much different than ours. In fact, in the study of Lebenthal et al., ghrelin changes were explored after being briefly exposed to supraphysiological estrogen, whereas in our study estrogen was chronically reduced by GnRHa treatment. It is reasonable to say that the ghrelin secretion process may be more sensitive to prolonged stimulation than to a single prime of estrogen. Moreover, the sample of rather short girls was eterogeneous in nature, most likely including both girls with idiopathic/familial short stature and children with constitutional growth delay. It is highly possible that girls with different underlying causes for their short stature may respond differently to sex hormone administration, as reported by authors themselves (17).

In our study, in spite of ghrelin reduction being paralleled by estrogen concentrations, at an individual level, the correlation analysis failed to demonstrate a relationship between ghrelin and estrogen changes. The lower limit of sensitiveness $(15 \mathrm{pmol} / \mathrm{l})$ of the serum $\mathrm{E}_{2}$ enzyme immunoassay used in this study may contribute to explain this finding. In fact, we did not have the chance to detect $\mathrm{E}_{2}$ values during treatment with GHRHa which were below the sensitivity threshold. This implies that, at least in some of the girls, the amplitude of the $\mathrm{E}_{2}$ reduction during treatment may be underestimated, affecting the individual relationship between ghrelin and $\mathrm{E}_{2}$ changes. 
Unfortunately, the serum of these patients is no longer available for further more sensitive measurements.

In conclusion, contrary to what happens in physiologic puberty, where ghrelin progressively decreases, acute inhibition of puberty by GnRHa treatment in girls with CPP was not associated with an increase in ghrelin concentrations, but with a reduction. Therefore, ghrelin seems to be independent from pubertal development per $s e$, while it is possible that its changes are related to chronological advancing. Moreover, contemporaneous estrogen decrease during treatment suggests that, in accordance with other results in animal and human studies, estrogen may play a potential role in the regulation of ghrelin secretion. However, further studies are needed to clarify the involvement of ghrelin in the onset of puberty as well as in the potential mechanisms linking estrogen and ghrelin secretion in girls at puberty.

\section{References}

1 Harris DA, Van Vliet G, Egli CA, Grumbach MM, Kaolan SL, Styne DM \& Vainsel M. Somatomedin-C in normal puberty and in true precocious puberty before and after treatment with a potent luteinizing hormone-releasing hormone agonist. Journal of Clinical Endocrinology and Metabolism 198561 152-159.

2 Pescovitz OH, Rosenfeld RG, Hintz RL, Barnes K, Hench K, Comité F, Loriaux D \& Cutler GB. Somatomedin-C in accelerated growth of children with precocious puberty. Journal of Pediatrics $198510720-25$.

3 Di Martino-Nardi J, Wu R, Varner R, Wong WL \& Saenger P. The effect of luteinizing hormone-releasing hormone analog for central precocious puberty on growth hormone $(\mathrm{GH})$ and $\mathrm{GH}$-binding protein. Journal of Clinical Endocrinology and Metabolism 199478 664-668.

4 Cisternino M, Draghi M, Lauriola S, Scarcella D, Bernasconi S, Cavallo L, De Luca F, Lomeo A \& Tato L. The acid-labile subunit of human ternary insulin-like growth factor-binding protein complex in girls with central precocious puberty before and during gonadotropin-releasing hormone analog therapy. Journal of Clinical Endocrinology and Metabolism 200287 4629-4633.

5 Mansfield MJ, Rudlin CR, Crigler JF Jr, Karol KA, Crawford JD, Boepple PA \& Crowley WF Jr. Changes in growth and serum growth hormone and plasma somatomedin-C levels during suppression of gonadal sex steroid secretion in girls with central precocious puberty. Journal of Clinical Endocrinology and Metabolism 1988 66 3-9.

6 Tannenbaum GS \& Bowers CY. Interactions of growth hormone secretagogues and growth hormone-releasing hormone/somatostatin. Endocrine 200114 21-27.

7 Kojima M, Hosoda H, Date Y, Nakazato M, Matsuo H \& Karngawa K. Ghrelin is a growth-hormone releasing acylated peptide from the stomach. Nature 1999402 656-660.

8 Kojima M, Hosoda H, Matsuo H \& Karngawa K. Ghrelin: discovery of the natural endogenous ligand for the growth hormone secretagogue receptor. Trends in Endocrinology and Metabolism 200112 118-122.

9 Tschop M, Smiley DL \& Heiman ML. Ghrelin induces adiposity in rodents. Nature $2000 \mathbf{4 0 7} 908-913$.

10 Cummings DE, Purnell JQ, Frayo RS, Schmidova K, Wisse BE \& Weigle DS. A preprandial rise in plasma ghrelin levels suggests a role in meal initiation in humans. Diabetes 200150 1714-1719.

11 Wren AM, Small CJ, Abbott CR, Dhillo WS, Seal LJ, Cohen MA, Batterham RL, Taheri S, Stanley SA, Ghatei MA \& Bloom SR. Ghrelin causes hyperphagia and obesity in rats. Diabetes 200150 2540-2547.
12 Nakazato M, Murakami N, Date Y, Kojima M, Matsuo H, Kangawa K \& Matsukura S. A role for ghrelin in the central regulation of feeding. Nature 2001409 194-198.

13 Wren AM, Seal LJ, Cohen MA, Brynes AE, Frost GS, Murphy KG, Dhillo WS, Ghatei MA \& Bloom SR. Ghrelin enhances appetite and increases food intake in humans. Journal of Clinical Endocrinology and Metabolism 2001865992.

14 Kletter GB, Cemeroglu AP, Foster CM, Frayo RS \& Cummings DE. Serum ghrelin concentrations after an overnight fast in children and adolescents. A cross-section study. Proceedings of the 84th Annual Meeting of the Endocrine Society 2002 pp 0R23-25.

15 Whatmore AJ, Hall CM, Jones J, Westwood M \& Clayton PE. Ghrelin concentrations in healthy children and adolescents. Clinical Endocrinology 200359 649-654.

16 Soriano-Guillen L, Barrios V, Chowen JA, Sanchez I, Vita S, Quero J \& Argente I. Ghrelin levels from fetal life through early adulthood: relationship with endocrine and metabolic and anthropometric measures. Journal of Pediatrics 2004144 30-35.

17 Lebenthal Y, Yablonsky GG, Shtaif B, Padoa A, Phillip M \& Lazar L. Effect of sex hormone administration on circulating ghrelin levels in peripubertal children. Journal of Clinical Endocrinology and Metabolism 200525 328-331.

18 Mansfield MJ, Beardsworth DE, Loughlin JS, Crawford JD, Bode HH, Rivier J, Vale W, Kushner DC, Crigler JF Jr \& Crowley WF Jr. Long-term treatment of central precocious puberty with a long-acting analogue of luteinizing hormone-releasing hormone. Effects on somatic growth and skeletal maturation. New England Journal of Medicine 1983309 1286-1290.

19 Luciano A, Bressan F \& Zoppi G. Body mass index reference curves for children aged 19 years from Verona, Italy. European Journal of Clinical Nutrition 199751 6-10.

20 White EM, Wilson AC, Greene SA, McCowan C, Thomas GE, Cairns AY \& Ricketts LW. Body mass index centile charts to assess fatness of British children. Archives of Disease in Childhood 199572 38-41.

21 Dietz WH \& Robinson TN. Use of body mass index (BMI) as a measure of overweight in children and adolescents. Journal of Pediatrics 1998132 191-193.

22 Pietrobelli A, Faith MS, Allison DB, Gallagher D, Chiumello G \& Heymsfield SB. Body mass index as a measure of adiposity among children and adolescents: a validation study. Journal of Pediatrics 1998132 204-210.

23 Tanner IM, Whitehouse RH \& Takaishi M. Standards for birth to maturity for height, weight, height and weight velocity: British children 1965. Archives of Disease in Childhood 196641 454-495.

24 Greulich WW \& Pyle SI. Radiographic Atlas of Skeletal Development of the Hand and Wrist. 2nd edn. Stanford, CA: Stanford University Press, 1959.

25 Tschop M, Weyer C, Tataranni PA, Devanarayan V, Ravussin E \& Heiman ML. Circulating Ghrelin levels are decreased in human obesity. Diabetes 200150 707-709.

26 Shah N, Evans WS, Bowers CY \& Veldhuis JD. Tripartite neuroendocrine activation of the human growth hormone $(\mathrm{GH})$ axis in women by continuous 24-hour GH-releasing peptide infusion: pulsatile, entropic, and nycohemeral mechanisms. Journal of Clinical Endocrinology and Metabolism 199984 2140-2150.

27 Matsubara M, Sakata I, Wada R, Yamazaki M, Inoue K \& Sakai T. Estrogen modulates ghrelin expression in the female rat stomach. Peptides 200425 289-297.

28 Kellokoski E, Poykko SM, Karjalainen AH, Ukkola O, Heikkinen J, Kesaniemi YA \& Horkko S. Estrogen replacement therapy increases plasma ghrelin levels. Journal of Clinical Endocrinology and Metabolism 200590 2954-2963.

Received 6 August 2006

Accepted 16 October 2006 